\title{
Uludağ Göknarı ve Sarıçam İbrelerinin Bazı Kimyasal Bileşiklerinin Meşcere Yaşına ve Bazı Toprak Özelliklerine Bağlı Olarak Değişimi
}

\author{
Nezahat Turfan*1, Gamze Savacı², Temel Sarıyıldız ${ }^{2}$ \\ ${ }^{1}$ Kastamonu Üniversitesi, Fen-Edebiyat Fakültesi, Biyoloji Bölümü, Kastamonu \\ ${ }^{2,3}$ Kastamonu Üniversitesi, Orman Fakültesi, Orman Mühendisliği Bölümü, Kastamonu \\ *Sorumlu yazar: nturfan@kastamonu.edu.tr
}

Geliș Tarihi: 27.06.2016

\begin{abstract}
Özet
Ormanlar karbondioksitin bağlanması, su ve mineral döngüsü, toprak ve suyun korunması, iklimin düzenlenmesi ve en önemlisi atmosferdeki oksijenin sağlanması gibi ekolojik fonksiyonları düzenlediği gibi ekonomik ve sosyokültürel olarak da faydalar sunan doğal kaynaklardır. Göknar ve sarıçam herdem yeşil, ekolojik çeşitlilik ve ekonomik olarak önemli orman ağaçlarındandır. Burada sunulan çalışmada, Kastamonu yöresinde yayılış gösteren Uludağ göknarı (Abies nordmanniana subsp. bornmulleriana Mattf.) ve sarıçamın (Pinus sylvestris L.) ibrelerinin kimyasal içerikleri üzerinde ağaç yaşı ve bazı toprak özelliklerinin etkilerinin belirlenmesi amaçlanmıştır. $\mathrm{Bu}$ amacı gerçekleştirmek için, farklı yaş gruplarındaki Uludağ göknar $(38,60,90,100)$ ve sarıçam $(18,30)$ ağaçlarından alınan ibre örneklerinin fotosentetik pigment (klorofil and karotenoit), prolin, toplam çözünür protein, glikoz, fruktoz, sakkaroz, nişasta miktarı, lipit peroksidasyon seviyesi (MDA, malondialdehit), hidrojen peroksit $\left(\mathrm{H}_{2} \mathrm{O}_{2}\right)$ konsantrasyonu, askorbat peroksidaz (APx), guaiakol peroksidaz (GPx), katalaz (CAT) ve süperoksitdismutaz (SOD) aktiviteleri belirlenmiştir. Elde edilen sonuçlara göre, 90 yaşındaki Uludağ göknarı ibrelerinde pigment, glikoz, nişasta, MDA ve $\mathrm{H}_{2} \mathrm{O}_{2}$ miktarı, APx, GPx ve CAT aktivitesi en yüksek bulunurken, prolin ve protein miktarları en düşük bulunmuştur. 38 yaşındaki Uludağ göknarı ibrelerinde ise prolin and protein miktarı en yüksek tespit edilirken, pigment, şeker, nişasta ve MDA miktarı ise daha düşük belirlenmiştir. 60 yaşındaki Uludağ göknarı ibrelerinde ölçülen aynı parametreler ise en düşük miktarlara sahip olmuştur. 18 yaşındaki sarıçam ibrelerinde fotosentetik pigment, prolin ve protein miktarı, APx, GPx ve CAT aktivitesi yüksek bulunurken, şeker ve nişasta miktarı ile SOD aktivitesi ise 30 yaşındaki ibrelerde daha yüksek bulunmuştur. Sonuç olarak, 90 yaşındaki Uludağ göknarı ile 18 yaşındaki sarıçamın diğer yaş gruplarına göre daha üstün özelliklere sahip olduğu; her iki tür ele alındığında ise Uludağ göknarının daha tolerant bir tür olduğu tespit edilmiştir. Bu sonuçlara ek olarak, orman ağaçlarının toprak özelliklerine göre gösterdiği davranışlarının ağaç türü ve ağaç yaşına göre farklılıklar gösterdiği sonucuna varılmıştır. Bununla beraber, kesin bir sonuca varabilmek için daha fazla ağaç türlerini ve farklı yaşları kapsayan daha detaylı çalışmalara ihtiyaç bulunmaktadır.
\end{abstract}

Anahtar Kelimeler: Uludağ Göknarı, Sarıçam, Ağaç Yaşı, Kimyasal İçerikler

Variation in Some Chemical Compounds of the Uludağ fir and Scots Pine Needles in relation to Stand Age and Some Soil Properties

Abstract

Forests are natural resources that bind carbon dioxide, regulate water and mineral cycling, protect soil and water, influence climate and the most importantly provide oxygen in atmosphere as such they also offer economic and sociocultural benefits. Fir and pine are evergreen and they are ecologically and economically important forest trees. This present study aimed at determining the effects of age and soil properties on some chemical compounds in needles of Uludağ fir (Abies nordmanniana subsp. bornmulleriana) and Scots pine (Pinus sylvestri L.) tree species growing in Kastamonu region in Turkey. The needle samples were collected from different tree-age classes of Uludağ fir $(100,90,60$ and 38 yearold) and Scots pine (30 and 18 year-old), and analyzed for photosynthetic pigment, proline, total soluble protein, glucose, fructose, sucrose, starch (polysaccharide), peroxidation level (MDA-malondialdehyde), $\mathrm{H}_{2} \mathrm{O}_{2}$, APx, GPx, CAT and SOD activities. Results showed that 90 year-old fir needles had the highest photosynthetic pigment, glucose, starch (polysaccharide), MDA, $\mathrm{H}_{2} \mathrm{O}_{2}$, APx, GPx and CAT activity, whereas they showed the lowest prolin and protein. 38 year-old fir needles showed the highest proline and protein, but had lower photosynthetic pigment, glucose, starch and MDA (malondialdehyde). As for Scots pine, 18 year-old needles had higher photosynthetic pigment, proline, protein, APx, GPx and CAT activities, while 30 year-old needles had higher glucose, starch and SOD activity. When all results are 
evaluated, it is seen that 90 year-old fir tree and 18 year-old Scots pine tree have superior properties, but among two tree species are compared, fir trees are more tolerant species than Scots pine. In addition, it is also concluded that the behavior of forest trees with soil properties show variation with tree species and tree age. However, more detailed studies using different tree species and tree ages are needed to reach the final conclusion.

Keywords: Turkish Fir, Scots Pine, Tree Age, Chemical Constituents

\section{Giriș}

Canlı organizma, çevresiyle sürekli olarak enerji ve madde alışverişi yapan açık bir sistemdir. Ekosistemlerdeki madde ve enerji akışının anahtar basamağını oluşturan bitkiler; yaşamları süresince kuraklık, hava ve toprak kirliliği, toprak yapısının bozulması, mineral yetersizliği, düşük ya da yüksek sıcaklık, yüksek 1şık şiddeti, bilinçsiz arazi kullanımı gibi olumsuz stres koşullarına maruz kalabilmektedir (Levitt, 1980; Lichtenhaler, 1996; Kadıŏlu, 2004).

Toprağın fiziksel, kimyasal özellikleri ve kimyasal bileşimi, doğal bir ekosistemde ya da tarımsal bir bölgede, belirli bir alanda hangi çeşit bitkinin yetişebileceğini belirleyen temel unsurlardır. Toprağın yapısı, su tutma kapasitesi, oksijen miktar1, $\mathrm{pH}$, organik madde ve humus miktar1, mineral madde içeriği, bitkilerin su ve suda çözünmüş moleküllerin ve ayrıca organik bileşiklerin alınmasını etkileyerek, bitki büyüme ve gelişmesinde önemli rol oynamaktadir. $\mathrm{Bu}$ nedenle de bitkilerin büyüme ve gelişim modelleri toprağın özelliklerinin kalitesini yansıtmaktadır (Rowell, 1994; Viet ve ark., 2013). Bununla birlikte bitkilerin yeryüzünde dağılımı ve çevresel faktörlere tolerans gücü, bitkinin genetik yapısına, yetiştiği ortamın yükseltisine, rekabet gücüne, stresten kaçınma veya adaptasyon kabiliyetine, stresin şiddeti, süresi ve çeşidi, strese maruz kaldığı döneme (çimlenme, fide, çiçeklenme vb) ve bitki yaşı gibi özelliklere bağlı olarak değişebilmektedir (Wang ve ark., 2000; Berges ve ark., 2005; Sariyildiz ve Küçük, 2009).

Birçok araştırıcı; bitki türüne, çevresel faktörlere, toprağın fiziksel ve kimyasal özelliklerine (Makineci, 1999; Berges ve ark., 2005; Ponge ve Chevalier, 2006; Sariyildiz ve Anderson, 2006) ve bitkinin yaşam döngüsü içerisindeki safhalarına bağlı olarak bitkilerdeki fotosentetik pigmentlerin (Gitelson ve ark., 2002; Smirnoff, 2005;
Kruger ve Volin, 2006), prolin (Lutts ve ark., 1996; Keyvan, 2010; Türkyılmaz ve ark., 2011), çözünür proteinin (Yadeghari ve ark., 2008), glikoz, früktoz, sakkaroz gibi çözünür karbohidratlar ve şeker alkoloitlerin (Huber ve Huber, 1996), lignin, selüloz ve pektin gibi polisakkaritlerin (Sarıyıldız ve Anderson, 2006; Moura ve ark., 2010; Moura-Sobczak ve ark., 2011), süperoksit dismutaz (SOD), katalaz (CAT), guaiakol peroksidaz (GPx) ve Askorbat peroksidaz (APx) gibi antioksidant enzim aktivitlerinin (Choudhury ve Panda, 2004; Foyer ve Noctor, 2005; Cruz ve ark., 2013) değiştiğini bildirmişlerdir. Sözkonusu bu bileşikler, bitkinin büyüme ve gelişim fizyolojisini düzenledikleri gibi abiyotik ve biyotik stres faktörlerin toleransında rol oynamaktadırlar (Marschner, 1995; Wang, 2000; Bond, 2000; Keyvan, 2010). Bununla beraber, ülkemiz asli orman ağaç türleri üzerinde bu konuda yapılmış çalışmaların oldukça az olduğu görülmektedir.

Bitkilerde büyüme ve gelişmenin, fotosentez ve solunum metabolizmasinın dengesine bağlı olarak gerçekleştiği bilinmektedir (Bauer ve Bauer, 1980; Atkin ve ark., 2007; Smith ve ark., 2011). Aktif büyümenin baskin olduğu juvenil fazda katabolizma hızlı olduğu, gelişmenin ilerlediği olgunlaşma fazında ise katabolizma ve anabolizmanın dengelendiği, fakat gelişmenin tamamen tamamlandiğı ve yaşlanmanın başladığı evrede ise katabolizmanın düştüğü, anabolizmanın ise arttığı bildirilmiştir (Krömer, 1995; Eubel ve ark., 2003; Kruger ve Volin, 2006; Gregersen ve ark., 2013).

Ormanlar, insanlar ve diğer canlılar için hayati öneme haiz, karbondioksit gazının yapraklarca bağlanması, su ve mineral döngüsü, toprak ve suyun korunması, iklimin düzenlenmesi gibi pek çok ekolojik fonksiyonları yerine getirmektedir (Sevik ve ark., 2015;2016). Bu fonksiyonları yerine getirirken, yetiştiği ortam özelliklerinde 
meydana gelen değişimler ağaçların morfolojik, anatomik ve kimyasal özelliklerinde bazı değişikliklere neden olmaktadır. Orman Genel Müdürlüğü tarafindan 2015 yılında yayınlanan "Türkiye Orman Varlı̆̆ı Kitabı'na göre ülkemizin orman varlığ 22.342 .935 hektardır. $\mathrm{Bu}$ orman varlığımız içinde önemli bir yer tutan asli ağaç türleri arasında yer alan sarıçam ormanlar1 1.518.929 hektar $(\% 6.80)$ ile 5. sırada yer alırken, göknar ormanları 584.781 hektar (\%2.62) ile 7. sirada yer almaktadır. Kastamonu ilinin yüz ölçümünün yaklaşık \%66's1 (889.817 hektar) ormanlarla kaplı olup, sarıçam ormanları tüm orman varlığ içinde $\% 8$ ile (66.757 hektar) 3. sırada yer alırken, sarıçam ormanlarını \%5 ile (43.167 hektar) Uludağ göknarı takip etmektedir (URL1, 2016).

Hem ülkemizde hem de Kastamonu ili sınırları içinde yayılış gösteren iki orman ağac1 türünün şu ana kadar yayılışı, büyümesi, yetişme ortamı özellikleri, silvikültürel özellikleri, odunu ve ekolojik özellikleri üzerine birçok çalışma gerçekleştirilmiş (Şimşek ve Öner, 2003; Sarıyıldız ve Anderson, 2005; Şenyurt ve Saraçoğlu, 2012; Şevik ve ark., 2012) olmasına rağmen, bu türlerimizin ibrelerinin kimyasal özellikleri üzerinde ağaç ve toprak özelliklerinin etkileri konusunda yeterli çalışma bulunmamaktadır. Sarıyıldız ve Anderson (2006) tarafından gerçekleştirilen bir çalışmada, farklı toprak özelllikleri üzerinde yetişen Sarıçam ağacı ibrelerinin aynı dal üzerinde oluşturdukları farklı yıllara ait ibrelerinin (aynı dal üzerinde son üç yıla ait ibreler) besin elementlerinin ve kimyasal bileşiklerinin önemli derecede farklılık gösterdiği fakat bu farklılığın derecesinin toprak özelliklerine göre değişiklik gösterdiği bildirilmiştir.

Burada sunulan çalışmada temel amaç, Kastamonu yöresinde yayılış gösteren asli ağaç türlerinden sarıçam (Pinus sylvestris $\mathrm{L}$.) ve Uludağ göknarı (Abies nordmanniana subsp. Bornmulleriana Mattf.) türlerinin ibrelerinin fotosentetik pigmentler, prolin, toplam çözünür protein, glukoz, fruktoz, sakkaroz, toplam nişasta, lipit peroksidasyon (MDA-MalonDiAldehit) seviyesi, hidrojen peroksit $\left(\mathrm{H}_{2} \mathrm{O}_{2}\right)$ konsantrasyonu, SOD, CAT, APx ve GPx aktivitesi üzerinde ağaç yaşının ve bazı toprak özelliklerinin etkilerinin belirlenmesidir.

\section{Materyal ve Metot}

\section{Çalışma Alanının Tanıtımı:}

Bu çalışma, Kastamonu İli İnebolu İlçesi Orman İşletmesi sınırları içerisinde yer alan (41 ${ }^{\circ} 51^{\prime} 23^{\prime \prime}-41^{\circ} 51^{\prime} 56^{\prime \prime} \mathrm{K}, 33^{\circ} 45^{\prime} 36^{\prime \prime}-33^{\circ} 45^{\prime} 19^{\prime \prime}$ D) farklı yaşlardaki Uludağ göknarı $(38,60$, 90 ve 100 yillık) ile sarıçam (18 ve 30 yıllık) meşçerelerinde alınan deneme alanlarında $(20 \times 20 \mathrm{~m})$ gerçekleştirilmiştir (Şekil 1). Çalışma alanın ortalama yükseltisi $1030 \mathrm{~m}$, ortalama eğimi $\% 20$ ve hakim bakısı kuzeydoğudur. Çalışılan her iki türe ait meşcereler asli türler olup, orman altı ise yaygın olarak otlar, eğreltiler ve çalı türleriyle kaplı bulunmaktadır.

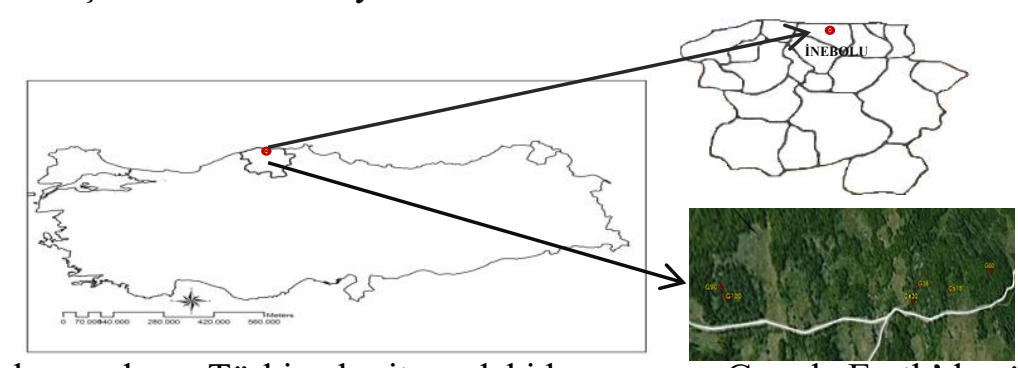

Şekil 1. Çalışma alanın Türkiye haritasındaki konumu ve Google Earth'de görüntüsü

Çalıșma alanına en yakın, İnebolu Meteoroloji İstasyonunun (64 m yükseklikte) 1980-2015 y1lına ait verilerinin (DMİ, 2016) enterpole değerlerine göre (Tablo 1) çalışma alanının yıllık ortalama yağışı $1661.9 \mathrm{~mm}$, yă̆ģıın en yüksek olduğu ay Ekim (273.3 $\mathrm{mm})$, en düşük olduğu ay ise Ağustos ayıdır $(80.1 \mathrm{~mm})$. Yillik ortalama sicaklık $13.9^{\circ} \mathrm{C}$, potansiyel evapotransprasyon $763.7 \mathrm{~mm}$, gerçek evapotrasprasyon $701 \mathrm{~mm}$, su noksanı $62.7 \mathrm{~mm}$ ve su fazlas 1 ise $960.9 \mathrm{~mm}$ dir. 
Tablo 1. Thornthwaite yöntemine göre çalışma alanının su bilançosu

Bilanço

AYLA R

YILLI elemanları

\begin{tabular}{|c|c|c|c|c|c|c|c|c|c|c|c|c|c|c|}
\hline & & I & II & III & IV & $\mathbf{V}$ & VI & VII & VIII & IX & $\mathbf{X}$ & XI & XII & \\
\hline Sicaklık & ${ }^{\circ} \mathrm{C}$ & 7.3 & 6.6 & 8.4 & 11.4 & 16.3 & 21.0 & 23.9 & 25.1 & 21.0 & 15.9 & 12.2 & 8.5 & 13.9 \\
\hline Sicaklık indisi & & 1.77 & 1.52 & 2.19 & 3.48 & 5.98 & 8.78 & $\begin{array}{l}10.6 \\
8\end{array}$ & 11.5 & 8.78 & 5.76 & 3.86 & 2.23 & 66.53 \\
\hline $\begin{array}{l}\text { Düzeltilmemi } \\
\text { ș PE }\end{array}$ & $\mathrm{mm}$ & 17.5 & 15.5 & 24.0 & 34.0 & 61.0 & 90.0 & $\begin{array}{l}110 . \\
0\end{array}$ & $\begin{array}{l}120 . \\
0\end{array}$ & 90.0 & 59.0 & 39.0 & 24.5 & \\
\hline $\begin{array}{l}\text { Düzeltilmiş } \\
\mathrm{PE}\end{array}$ & $\begin{array}{l}\mathrm{PE} \\
\mathrm{T}\end{array}$ & 14.5 & 12.9 & 24.7 & 37.7 & 76.3 & $\begin{array}{l}113 . \\
4\end{array}$ & $\begin{array}{l}139 . \\
7\end{array}$ & $\begin{array}{l}142 . \\
8\end{array}$ & 93.6 & 56.6 & 31.9 & 19.6 & 763.7 \\
\hline Yağı̆ş & $\mathrm{y}$ & $\begin{array}{l}135 . \\
2\end{array}$ & $\begin{array}{l}138 . \\
9\end{array}$ & $\begin{array}{l}113 . \\
6\end{array}$ & $\begin{array}{l}103 . \\
4\end{array}$ & 96.2 & $\begin{array}{l}108 . \\
1\end{array}$ & $\begin{array}{l}104 . \\
4\end{array}$ & 80.1 & $\begin{array}{l}158 . \\
4\end{array}$ & $\begin{array}{l}273 . \\
3\end{array}$ & $\begin{array}{l}161 . \\
6\end{array}$ & 188.7 & $\begin{array}{l}1661 . \\
9\end{array}$ \\
\hline $\begin{array}{l}\text { Depo } \\
\text { Değișikliği }\end{array}$ & Dd & 0 & 0 & 0 & 0 & 0 & 5.3 & 94.7 & 0 & 64.8 & 35.2 & 0 & 0 & \\
\hline Depolama & $\mathrm{D}$ & 100 & 100 & 100 & 100 & 100 & 94.7 & 59.4 & 0 & 64.8 & 100 & 100 & 100 & \\
\hline $\begin{array}{l}\text { Gerçek } \\
\text { Evapotranspra } \\
\text { sy. }\end{array}$ & $\begin{array}{l}\mathrm{GE} \\
\mathrm{T}\end{array}$ & 14.5 & 12.9 & 24.7 & 37.7 & 76.3 & $\begin{array}{l}113 . \\
4\end{array}$ & $\begin{array}{l}139 . \\
7\end{array}$ & 80.1 & 93.6 & 56.6 & 31.9 & 19.6 & 701.0 \\
\hline Su Noksan1 & $\mathrm{Sn}$ & 0 & 0 & 0 & 0 & 0 & 0 & 0 & 62.7 & 0 & 0 & 0 & 0 & 62.7 \\
\hline Su Fazlası & Sf & $\begin{array}{l}120 . \\
7\end{array}$ & 126 & 88.9 & 65.7 & 19.9 & 0 & 59.4 & 0 & 0 & $\begin{array}{l}181 . \\
5\end{array}$ & $\begin{array}{l}129 . \\
7\end{array}$ & 169.1 & 960.9 \\
\hline $\begin{array}{l}\text { Yüzeysel } \\
\text { Akış }\end{array}$ & Y & $\begin{array}{l}144 . \\
9\end{array}$ & $\begin{array}{l}123 . \\
3\end{array}$ & $\begin{array}{l}107 . \\
5\end{array}$ & 77.3 & 42.8 & 9.9 & 29.7 & 29.7 & 0 & 90.8 & $\begin{array}{l}155 . \\
6\end{array}$ & 149.4 & 960.9 \\
\hline $\begin{array}{l}\text { Nemlilik } \\
\text { Oranı }\end{array}$ & $\mathrm{Ne}$ & 83.2 & 97.7 & 36.0 & 17.4 & 2.6 & 0 & -2.5 & -4.4 & 6.9 & 38.3 & 40.7 & 86.3 & \\
\hline
\end{tabular}

İklim Tipi

A B'2 r b'4: Çok nemli, orta sıcaklıkta (Mezotermal), su noksanı olmayan veya pek az olan, okyaus iklimine yakın iklim

\footnotetext{
Maden Tetkik Arama (MTA)

Müdürlüğü’nün hazırlamıs olduğu 1/500.000 ölçekli jeoloji haritası incelendiğinde; 90 ve 100 yaşındaki Uludağ göknarı meşcerelerinin bulunduğu topraklar, orta-kalın tabakalı, bol eklemli, gri-bej renkli, masif yapılı, Kreatese-Orta Jura devrine ait olup, neritik kireçtaş1 ana kayasından gelişmiştir. Sarıçam türü ile 38 ve 60 yaşındaki göknar türünün toprakları ise; Triyas-Alt Jura devrine ait olan şist ana kayasından gelişmiştir (Akbaş ve ark., 2014). Toprak derinliği bakımından sı ̆ olan topraklar, sarıçam meşcerelerinde killi balçık (S18, S30), Uludağ göknarı meșcerelerinde ise; genellikle killi (G38, G60) ve kumlu balçık (G90 ve G100) topraklardan oluşmaktadır. $\mathrm{Bu}$ alandaki toprak profil örneklerinde $\mathrm{Ah}$ ve $\mathrm{C}$ horizonu açık bir şekilde belirgin iken B horizonu oluşumu genelde belirgin değildir.
}

\section{Meşcere özelliklerinin belirlenmesi}

Farklı yaşlardaki Uludağ göknarı ve Sarıçam meşçerelerinde alınan deneme alanlarının ortalama yaşı, çap1 ve kapalılığı belirlenmiştir. Yaş tayini her bir deneme alanında üç galip ağacın göğüs yüksekliğinden $(1.30 \mathrm{~m})$ Pressler artım burgusu ile alınan artım kalemleri üzerinde yıllık halkalar sayılarak tespit edilmiştir. Ayrıca, bu sayıya civarında $1.30 \mathrm{~m}$ boyundaki birkaç fidanda tespit edilen ortalama yaş da ilave edilmiştir. Artım burgusuyla ağacin yaşını belirlerken; ekzantrik büyüme ile yıllık halka ölçümünde meydana gelebilecek hatayı önlemek için artım kalemlerinin birbirine dik iki yönde olmasına dikkat edilmiştir (Carus, 1995). Aynı galip ağaçların çapları ağacın üst yamacından olmak üzere, çapraz olarak $\mathrm{cm}$ 
duyarl111kla göğüs yüzeyinden ağaç çap ölçer yardımıyla belirlenmiştir.

Deneme alanlarının kapalılığ 1 ise bilgi ve deneyimden yararlanılarak tahmini olarak belirlenmiş, daha sonar karşılaştırma yapmak amaciyla meşcerelere ait amenajman ve meşçere haritalarından yararlanılmıştır.

\section{Toprak, ibre ve ölü örtü örneklemesi}

Mineral toprak örneklemesi deneme alanlarında açılan toprak çukurunun $0-30 \mathrm{~cm}$ derinlik kademesinden yapılmıştır. Toprak hacim ağırlığını belirlemek amacıyla ise aynı deneme alanından toprak silindirleri yardımıyla yapısı bozulmamış toprak örneklemesi yapılmıştır. Farklı yaşlardaki ağaç üzerinde yapılan taze ibre örneklemesi, her bir yaş sınıfını temsil edecek şekilde rastgele seçilen 6 farklı ağacın alt dallarından yapılmış ve örnekler daha sonra karıştırılarak her bir yaş sınıfi için homojen hale getirilmiştir. Ölü örtü örneklemesi ise deneme alanında alınan 50x50 cm genişliğindeki 3 deneme parselinde organik horizonlar (L-ölü örtü, F-çürüntü tabakası ve H-humus horizonları) dikkate alınarak gerçekleştirilmiştir. Organik horizonların kalınlıkları cetvel yardımıyla ölçülmüştür. Her bir organik horizon tabakasındaki organik materyal elle toplanarak ayrı ayrı plastik torbalara konulmuş ve ağırlıklarının belirlenmesi amaciyla laboratuvara götürülmüştür. Alınan örnekler laboratuvarda firın kurusu hale getirildikten sonra ağırlıkları hesaplanmıştır.

A ğırlıkları belirlenen organik horizonlardan yararlanarak ölü örtü miktarı kg ha-1 olarak ifade edilmiştir.

\section{Toprak örneklerinin analizi}

Laboratuvarda hava kurusu hale gelmiş toprak örnekleri porselen havanda ezilmiş ve daha sonra $2 \mathrm{~mm}$ 'lik eleklerden geçirilmiş ve plastik poşetlere konularak muhafaza altına alınmıştır. Analize hazır hale gelen toprak örneklerinin $\mathrm{pH}$, tekstür, hacim ağırlığı, organik madde, karbon ve potasyum miktarları belirlenmiştir. Toprak örneklerinin pH's1 1/2.5 oranındaki toprak- saf su karışımında dijital pH metre ile ölçülmüştür (Jackson, 1962; Gülçür, 1974). Tekstür tayini ise Bouyoucos'un hidrometre yöntemine göre belirlenmiştir (Bouyoucos, 1936; Irmak
1954; Bouyoucos, 1962).Toprak örneklerinin hacim ağırlıkları çelik silindir yardımıyla (Blake, 1965; Özyuvac1, 1976; Göl ve Öner, 2003) ve organik karbon $950-1000^{\circ} \mathrm{C}$ yüksek sıcaklıkta yaklaşık $2 \mathrm{mg}$ olarak tartılan örnekler yüksek saflıktaki oksijen gazı ile yakarak içerdiği Karbon $(\mathrm{C})$, Hidrojen $(\mathrm{H})$ ve Azot (N) elementlerini yüzdesel olarak kromatografik yollarla tayin eden Eurovector CHN Elemental Analyzer cihazla tespit edilmiştir (Chong ve ark., 2009; Choy ve ark., 2009; Eksperiandova ve ark., 2011). Ayrıca Kastamonu Üniversitesi Merkezi Araștırma Laboratuvarında bulunan SPECTRO marka XEPOS model, XRF cihazı yardımıyla toprak örneklerinin potasyum miktarı ppm cinsinden belirlenmiştir (Yurtseven ve ark., 2013).

\section{Taze ibre örneklerinin analizi}

Farklı yaş gruplarındaki Uludağ göknarı ve sarıçam ibrelerinin fotosentetik pigment miktarlar1 (klorofil a, klorofil b ve karotenoit), prolin, protein, lipid peroksidasyonu ve hidrojen peroksit $\left(\mathrm{H}_{2} \mathrm{O}_{2}\right)$ içerikleri, enzim, katalaz, askorbat peroksidaz, guaikol peroksidaz ve süper oksit dismutaz aktiviteleri ile toplam karbohidrat, glikoz, fruktoz ve sakkaroz miktarları belirlenmiştir.

Klorofil miktarının belirlenmesi için 0.5 gr taze yaprak dokusu sıvı azot içerisinde iyice ezilmiş ve üzerine $4^{\circ} \mathrm{C}^{\prime} \mathrm{de} \% 80^{\prime}$ lik aseton çözeltisinden $5 \mathrm{ml}$ ilave edilerek homojenize edilmiştir. Homojenat 3000 rpm'de 10 dakika santrifüj edilmiş ve alınan süpernatantın spektrofotometrede 450, 645, 663 nm'de ölçümleri üç tekrarlı yapılmıştır. Toplam klorofil miktarının belirlenmesinde Arnon denklemi (Arnon, 1949) kullanılmış karotenoid miktarı ise Jaspars formülüne göre belirlenmiştir (Witham ve ark., 1971).

Yaprak örneklerindeki prolin miktarı Bates ve ark. (1973), protein miktarı (Bradford (1976), Lipid peroksidasyonu (MDA) Lutts ve ark. (1996) ve $\mathrm{H}_{2} \mathrm{O}_{2}$ ekstraksiyonu Velikova ve ark. (2000) tarafindan kullanılan yöntemlere göre belirlenmiştir.

Glikoz, fruktoz ve sakkaroz miktarının belirlenmesi Pearson ve ark., (1976) Anthron metodu kullanılarak gerçekleştirilmiştir. Glikoz, fruktoz ve sakkaroz miktarı söz 
konusu bileşiklere ilişkin standart eğrileri ile $\mathrm{mg} / \mathrm{g}$ olarak belirlenmiştir. Nişasta tayini, glikoz miktarından belirlenmiştir.

Yaş ibre örneklerinin enzim aktivitelerinin belirlenmesinde, taze yaprak örneğinin 0.5 gramı sıv1 azotta ezilmiş ve içinde $0.1 \mathrm{mM}$ Na-EDTA bulunan 50 mM'llk (pH 7.6) $\mathrm{KH}_{2} \mathrm{PO}_{4}(\mathrm{pH}=7) \quad 5 \mathrm{ml}$ tampon çözeltisi ile homojenize edilmiştir. Homojenize edilen örnekler $15 \mathrm{dk}$ süre ile $15000 \mathrm{~g}$ ve $+4^{\circ} \mathrm{C}$ 'de santrifüjlenmiştir.

Askorbat peroksidaz aktivitesi (APx) spektrofotometrik olarak Nakano ve Asada (1981) tarafindan uygulanan yönteme göre 290 nm'de $(\mathrm{E}=2,8 \mathrm{mM} \mathrm{cm}-1)$ askorbatın oksidasyon hızı ölçülerek, Guaiakol peroksidaz aktivitesinin tayini (GPx) modifiye edilen yönteme göre (Lee ve Lin., 1995), Katalaz aktivitesi (CAT) spektrofotometrik olarak Bergmeyer (1974) tarafindan uygulanan yöntemine göre, süperoksitdismutaz (SOD) enzim aktivitesi Çakmak, (2002) tarafindan uygulanan yönteme göre belirlenmiştir.

\section{İstatiksel Analiz}

Farklı yaşlardaki Uludağ göknarı ve sarıçam ibrelerinin kimyasal bileşikleri (fotosentetik pigment, prolin, toplam çözünür protein, glikoz, fruktoz, sakkaroz, nişasta miktarı, lipit peroksidasyon seviyesi (MDA, malondialdehit), $\mathrm{H}_{2} \mathrm{O}_{2}$ konsantrasyonu, APx,
GPx, CAT ve SOD aktiviteleri) arasında önemli bir farklılı̆̆ının olup olmadığ üzerine SPSS programı (11. versiyon) kullanılarak Varyans Analizi (ANOVA) uygulanmıştır. ANOVA sonuçları doğrultusunda, farklılığın önem derecesi Tukey's testi yardımıyla belirlenmiştir.

\section{Bulgular \\ Çalışma alanlarının meşcere ve toprak özellikleri}

Farklı yaşlardaki Uludağ göknarı ve sarıçam meşcerelerinin yaş, çap, kapalılık ve ölü örtü durumu Tablo 2' de, mineral toprak özelliklerine ait bilgiler Tablo 3'te verilmiştir.

Meşcere kapalılığ1 aynı olan Uludağ göknarı meşcerelerinin ortalama çapları genç meşcerelerden yaşlı meşcerelere doğru bir artış gösterirken, ölü örtü miktarı genç meşcerelerden yaşlı meşcerelere doğru bir azalış göstermiştir. En yüksek ölü örtü miktarı $17.4 \mathrm{~kg}$ ha-1 ile 30 yaşındaki Uludağ göknarı meşcereleri altında bulunurken en düşük miktar ise $3.95 \mathrm{~kg}$ ha-1 ile 100 yaşındaki meşcerelerde tespit edilmiştir. Sarıçam meşcerelerinde ise; yaşa başlı olarak ölü örtü miktarında bir artış olduğu belirlenmiştir (Tablo 2). Organik horizon kalınlıklarıda (L, $\mathrm{F}$ ve $\mathrm{H}$ ) her iki türde meşcere yaşına bağlı olarak farklılıklar göstermiştir (Tablo 2).

Tablo 2. Farklı yaş gruplarındaki Uludağ göknarı ve sarıçamın bazı meşcere özellikleri ve meşcere altı organik horizonları

\begin{tabular}{llllcccc}
\hline Türler & $\begin{array}{l}\text { Yaş } \\
(\mathbf{y ı l})\end{array}$ & $\begin{array}{l}\text { Çap } \\
(\mathbf{c m})\end{array}$ & Kapalılık & $\begin{array}{c}\text { Toplä örtü miktarı } \\
(\mathbf{k g ~ h a - 1 )}\end{array}$ & $\begin{array}{c}\mathbf{L} \\
(\mathbf{c m})\end{array}$ & $\begin{array}{c}\mathbf{F} \\
(\mathbf{c m})\end{array}$ & $\begin{array}{c}\mathbf{H} \\
(\mathbf{c m})\end{array}$ \\
\hline \multirow{3}{*}{ Uludağ Göknarı } & 38 & 31 & 3 & 17.4 & 3.5 & 1.7 & 2.0 \\
& 60 & 42 & 3 & 10.1 & 3.2 & 3.0 & 2.5 \\
& 90 & 47 & 3 & 5.81 & 2.7 & 2.3 & 1.8 \\
& 100 & 48 & 3 & 3.95 & 1.5 & 1.0 & 1.5 \\
\hline Sarıçam & 18 & 14 & 2 & 1.75 & 0.5 & 0.7 & 0.8 \\
& 30 & 31 & 2 & 6.54 & 1.5 & 1.0 & 0.5 \\
\hline
\end{tabular}

Toprak pH değerleri Uludağ göknarı meşcerelerinde yaşa bağlı olarak artış gösterirken, sarıçam meşcerelerinde bir değişiklik tespit edilmemiştir. Genel olarak, her iki ağaç türü içinde yaşa bağlı olarak yüzde kum miktarında bir artış, yüzde kil ve toz miktarlarında ise bir azalma olduğu belirlenmiştir (Tablo 3).Organik madde miktarı yaşa bağlı olarak bir azalma yönünde iken; hacim ağırlığı yaşa bağlı olarak bir artış göstermiştir. Yüzde karbon miktarı her iki ağaç türünde de yaşa bağlı olarak önemli bir değişim göstermemiştir (Tablo 3). Toprak potasyum miktarı ise Uludağ göknarı meşcerelerinde yaşa bağlı olarak azalma 
gösterirken, sarıçam meşcerelerinde yaşa bağlı olarak artış göstermiştir (Tablo 3).

Tablo 3. Farklı yaş gruplarındaki Uludağ göknarı ve sarıçam meşcerelerinin bazı toprak özelliklerindeki değişimler

\begin{tabular}{|c|c|c|c|c|c|c|c|c|c|}
\hline Türler & $\begin{array}{l}\text { Yaş } \\
\text { (yll) }\end{array}$ & pH & $\begin{array}{l}\text { Kum } \\
(\%)\end{array}$ & $\begin{array}{l}\text { Toz } \\
(\%)\end{array}$ & $\begin{array}{l}\text { Kil } \\
(\%)\end{array}$ & $\begin{array}{l}\text { Organik } \\
\text { madde } \\
(\%)\end{array}$ & $\begin{array}{l}\text { Hacim } \\
\text { ağırlığı } \\
\text { (g cm-3) }\end{array}$ & $\begin{array}{c}\text { Karbon } \\
(\%)\end{array}$ & $\begin{array}{l}\text { Potasyum } \\
\quad(\text { ppm) }\end{array}$ \\
\hline \multirow{4}{*}{ Uludağ Göknarı } & 38 & 5.15 & 32 & 26 & 42 & 4.93 & 1.20 & 4.49 & 18430 \\
\hline & 60 & 5.73 & 8 & 38 & 54 & 3.69 & 1.16 & 4.19 & 16910 \\
\hline & 90 & 6.77 & 84 & 9 & 7 & 4.17 & 1.50 & 3.42 & 15900 \\
\hline & 100 & 6.66 & 76 & 15 & 9 & 3.56 & 1.41 & 4.39 & 13910 \\
\hline \multirow[t]{2}{*}{$\begin{array}{l}\text { Sarıçam } \\
\end{array}$} & 18 & 5.82 & 31 & 33 & 36 & 3.16 & 1.50 & 2.89 & 18520 \\
\hline & 30 & 5.77 & 41 & 31 & 29 & 2.70 & 1.72 & 2.92 & 24570 \\
\hline
\end{tabular}

Fotosentetik pigment (klorofil ve karotenoit) miktarları

Farklı yaş gruplarındaki Uludağ göknarı ve sarıçam ibrelerinin fotosentetik pigment miktarı (klorofil ve karotenoit) Tablo 4'te verilmiştir. İstatistiksel olarak ibrelerin içerdiği fotosentetik pigment miktarları yaş sinifları ve türler arasında önemli derecede farkl1lıklar göstermiştir $(\mathrm{p}<0.05)$. Yüz yaşındaki Uludağ göknarı ibreleri en düşük klorofil a, klorofil b, toplam klorofil ve karotenoit değerlerine sahip olurken, 90 yaşındaki Uludağ göknarı ibreleri en yüksek değerleri göstermiştir. Fotosentetik pigment miktarları, 30 yaşındaki ağaçlardan 60 yaşındaki ağaçlara doğru incelendiğinde önce bir azalma gösterdiği, 90 yaşındaki ağaçlara doğru arttığı ve 100 yaşındaki ağaçlarda ise bu değerlerin tekrar azaldığ tespit edilmiştir (Tablo 4). Sarıçam ibrelerinin de ilk y1llardaki fotosentetik pigment miktarlarının yaşa bağlı olarak azalma gösterdiği görülmüştür (Tablo 4). Bununla beraber, 18 yaşındaki sarıçam ibreleri klorofil a, klorofil b, toplam klorofil ve karotenoit değerleri bakımından en yüksek değerlere sahip olmuştur (Tablo 4).

Tablo 4. Farklı yaş gruplarındaki Uludağ göknarı ve sarıçam ibrelerindeki fotosentetik pigment miktarları ( $\mathrm{p}<0.05 ; \mathrm{a}, \mathrm{b}, \mathrm{c}, \mathrm{d}, \mathrm{e}, \mathrm{f}<0.000)$

\begin{tabular}{lccccc}
\hline Ăgaç türü & Yaş & $\begin{array}{c}\text { Klorofil a } \\
\text { mg g-1 }\end{array}$ & $\begin{array}{c}\text { Klorofil b } \\
\text { mg g-1 }\end{array}$ & $\begin{array}{c}\text { Toplam Klorofil } \\
\text { mg g-1 }\end{array}$ & $\begin{array}{c}\text { Toplam } \\
\text { Karotenoit } \\
\text { mg g-1 }\end{array}$ \\
\hline \multirow{3}{*}{ Uludağ Göknar1 } & 38 & $30.1 \pm 0.03 * \mathrm{c}$ & $25.1 \pm 0.008^{* \mathrm{c}}$ & $22.2 \pm 0.007 * \mathrm{~d}$ & $16.6 \pm 0.004^{* \mathrm{c}}$ \\
& 90 & $25.9 \pm 0.33^{* \mathrm{a}}$ & $20.0 \pm 0.06^{* \mathrm{~b}}$ & $17.8 \pm 0.05^{* \mathrm{~b}}$ & $14.6 \pm 0.022^{* \mathrm{~b}}$ \\
& 100 & $24.7 \pm 0.022^{* \mathrm{~d}}$ & $29.7 \pm 0.06^{*} \mathrm{~d}$ & $26.4 \pm 0.054^{*} \mathrm{e}$ & $18.0 \pm 0.02 * \mathrm{c}$ \\
\multirow{2}{*}{ Sarıçam } & 18 & $34.8 \pm 0.026^{*} \mathrm{~d}$ & $33.3 \pm 0.12^{* \mathrm{a}}$ & $15.8 \pm 0.082^{* \mathrm{a}}$ & $13.1 \pm 0.06^{* \mathrm{a}}$ \\
\hline
\end{tabular}

Prolin, protein, lipid peroksidasyonu ve $\mathrm{H}_{2} \mathrm{O}_{2}$ miktarları

Farklı yaş gruplarındaki Uludağ göknarı ve sarıçam ibrelerinin prolin, protein, lipid peroksidasyonu ve $\mathrm{H}_{2} \mathrm{O}_{2}$ miktarları Tablo 5'te verilmiştir. $\mathrm{Bu}$ miktarlar bakımından yaş sinıfları ve türler arasında önemli derecede $(\mathrm{p}<0.05)$ istatistiksel bir farklılığının olduğu tespit edilmiştir. Uludağ göknarı ibrelerinin prolin ve protein miktarları en yüksek 38 yaşındaki ağaçlarda en düşük ise; 100 yaşındaki ağaçlarda belirlenmiştir. Lipid peroksidasyonu malondialdehit (MDA) miktarı ise en yükssek 60 yaşındaki Uludağ göknarı ibrelerinde en düşük ise 100 yaşındaki Uludağ göknarı ibrelerinde belirlenmiştir. Hidrojen peroksit $\left(\mathrm{H}_{2} \mathrm{O}_{2}\right)$ miktarı ise MDA miktarına tezat olarak en düşük 60 yaşındaki Uludağ göknarı ibrelerinde, en yüksek 90 ve 100 yaşındaki Uludağ göknarı ibrelerinde tespit edilmiştir (Tablo 5). Sarıçam ibrelerinin prolin ve MDA miktarları yaşa bağlı olarak azalırken, 
hidrojen peroksit $\left(\mathrm{H}_{2} \mathrm{O}_{2}\right)$ miktarı ise yaşa bağl1 olarak artış göstermiş, protein miktarında ise bir değişiklik belirlenmemiştir (Tablo 5).

Glikoz, fruktoz, sakkaroz ve nişasta miktarları

Farklı yaş gruplarındaki Uludağ göknarı ve sarıçam ibrelerinin glikoz, früktoz, sakkaroz ve nişasta miktarları Tablo 6'da verilmiştir. Genç Uludağ göknarı ibrelerindeki (38 ve 60 yaş) glikoz, fruktoz, sakkaroz ve nişasta miktarları yaşlı Uludağ göknarı ibrelerden (90 ve 100 yaş) daha düşük bulunmuştur. Glikoz ve nişasta miktarları en yüksek 90 yaşındaki ibrelerde tespit edilirken (anılan siralamaya göre 174.8 mg g-1, 104.2 mg g-1), en düşük miktar 60 yaşındaki ibrelerde $(63.2 \mathrm{mg} \mathrm{g}-1,37.7 \mathrm{mg}$ g1) belirlenmiştir. Fruktoz ve sakkoraz miktarları en yüksek 100 yaşındaki ibrelerde bulunurken, en düşük früktoz miktarı 60 yaşındaki, en düşük sakkaroz miktarı ise 38 yaşındaki ibrelerde belirlenmiştir (Tablo 6). Sarıçam ibrelerinde ise glikoz, fruktoz, sakkaroz ve nişasta miktarları yaşa bağlı olarak artış göstermişlerdir (Tablo 6).

Tablo 5. Farklı yaş gruplarındaki Uludağ göknarı ve sarıçam ibrelerindeki prolin, toplam çözünür protein, malondialdehit (MDA) ve hidrojen peroksit $\left(\mathrm{H}_{2} \mathrm{O}_{2}\right)$ miktarları $(\mathrm{p}<0.05 ; \mathrm{a}, \mathrm{b}$, $\mathrm{c}, \mathrm{d}, \mathrm{e}, \mathrm{f}<0.000)$

\begin{tabular}{lcllll}
\hline \multirow{2}{*}{ Ağaç türü } & Yaş & $\begin{array}{l}\text { Prolin } \\
\boldsymbol{\mu g ~ g - 1}\end{array}$ & $\begin{array}{l}\text { Protein } \\
\mathbf{m g ~ m l - 1}\end{array}$ & $\begin{array}{l}\text { MDA } \\
\boldsymbol{\mu m o l ~ g - 1}\end{array}$ & $\begin{array}{l}\mathbf{H}_{2} \mathbf{O}_{2} \\
\boldsymbol{\mu m o l ~ g - 1}\end{array}$ \\
\hline \multirow{3}{*}{ Uludağ Göknar1 } & 38 & $788.4 \pm 0.15^{* \mathrm{e}}$ & $11.6 \pm 0.064^{* \mathrm{e}}$ & $33.73 \pm 0^{* \mathrm{~b}}$ & $84.6 \pm 0.083^{* \mathrm{~d}}$ \\
& 60 & $623.4 \pm 0.16^{* \mathrm{~b}}$ & $10.5 \pm 0.064^{* \mathrm{~d}}$ & $54.6 \pm 0.18^{* \mathrm{e}}$ & $34.64 \pm 0.2^{* \mathrm{~b}}$ \\
& 100 & $605.43 \pm 0.21^{* \mathrm{a}}$ & $7.31 \pm 0.051^{* \mathrm{~b}}$ & $45.4 \pm 0^{* \mathrm{~d}}$ & $136.74 \pm 0.17^{* \mathrm{f}}$ \\
\multirow{2}{*}{ Sarıçam } & 18 & $808.6 \pm 0.25^{* \mathrm{~d}}$ & $4.23 \pm 0.09^{* \mathrm{a}}$ & $28.72 \pm 0.1^{* \mathrm{a}}$ & $127.8 \pm 0.054^{* \mathrm{e}}$ \\
\hline
\end{tabular}

Tablo 6. Farklı yaş gruplarındaki Uludağ göknarı ve sarıçam ibrelerinin glikoz, fruktoz, sakkaroz ve nişasta miktarları ( $\mathrm{p}<0.05 ; \mathrm{a}, \mathrm{b}, \mathrm{c}, \mathrm{d}, \mathrm{e}, \mathrm{f}<0.000)$

\begin{tabular}{llllll}
\hline Ăgaç türü & $\begin{array}{l}\text { Yaş } \\
\text { (Yıl) }\end{array}$ & $\begin{array}{l}\text { Glikoz } \\
\text { mg g-1 }\end{array}$ & $\begin{array}{l}\text { Fruktoz } \\
\text { mg g-1 }\end{array}$ & $\begin{array}{l}\text { Sakkaroz } \\
\text { mg g-1 }\end{array}$ & $\begin{array}{l}\text { Nişasta } \\
\text { mg g-1 }\end{array}$ \\
\hline \multirow{4}{*}{ Uludağ Göknar1 } & 38 & $102.7 \pm 0.11^{* \mathrm{~d}}$ & $9.3 \pm 0.01^{* \mathrm{c}}$ & $4.8 \pm 0.03^{* \mathrm{c}}$ & $61.21 \pm 0.06^{* \mathrm{~d}}$ \\
& 60 & $63.21 \pm 0.06^{* \mathrm{a}}$ & $8.04 \pm 0.01^{* \mathrm{~b}}$ & $6.28 \pm 0.04^{* \mathrm{~d}}$ & $37.7 \pm 0.04^{* \mathrm{a}}$ \\
& 90 & $174.8 \pm 0.09^{* \mathrm{f}}$ & $13.1 \pm 0.01^{* \mathrm{~d}}$ & $10.07 \pm 0.04^{* \mathrm{e}}$ & $104.21 \pm 0.054^{* \mathrm{f}}$ \\
\multirow{2}{*}{ Sarıçam } & 100 & $114.05 \pm 0.06^{* \mathrm{e}}$ & $23.5 \pm 0.01^{* \mathrm{f}}$ & $15.6 \pm 0.08^{* \mathrm{f}}$ & $68 \pm 0.04^{* \mathrm{e}}$ \\
\hline & 18 & $66.72 \pm 0.11^{* \mathrm{~b}}$ & $7.7 \pm 0.012^{*} \mathrm{a}$ & $2.18 \pm 0.06^{* \mathrm{a}}$ & $39.8 \pm 0.07^{* \mathrm{~b}}$ \\
& 30 & $75.41 \pm 0.09^{* \mathrm{c}}$ & $14 \pm 0.01^{* \mathrm{e}}$ & $3.94 \pm 0.03^{* \mathrm{~b}}$ & $45 \pm 0.054^{* \mathrm{c}}$ \\
\hline
\end{tabular}

\section{Enzim aktiviteleri}

Farklı yaş gruplarındaki Uludağ göknarı ve sarıçam ibrelerinin askorbat peroksidaz (APx), guaikol peroksidaz (GPx), katalaz (CAT) ve süperoksit dismutaz (SOD) enzim aktiviteleri Tablo 7'de verilmiştir.

Askorbat peroksidaz (APx) enzim aktivitesi 100 yaşındaki Uludağ göknarı ibrelerinde en düşük belirlenirken, diğer yaş grupları arasında önemli bir farklılık tespit edilmemiştir (Tablo 7). Genç Uludağ göknarı ibrelerinde (38 ve 60 yaş) guaikol peroksidaz (GPx) ve süperoksitdismutaz (SOD) enzim aktiviteleri yaşlı Uludağ göknarı ibrelerinden
(90 ve 100 yaş) daha düşük bulunmuştur (Tablo 7). En yüksek guaiacol peroksidaz (GPx) enzim aktivitesi 90 yaşındaki ibrelerde iken en yüksek süperoksitdismutaz (SOD) enzim aktivitesi 100 yaşındaki ibrelerde belirlenmiştir. Katalaz (CAT) enzim aktivitesi ise en düşük 100 ve 38 yaşındaki ibrelerde belirlenirken, en yüksek ise 90 ve 60 yaşındaki ibrelerde tespit edilmiştir (Tablo 7). Sarıçam ibrelerinde ise yaşa bağlı olarak askorbat peroksidaz (APx), guaiacol peroksidaz (GPx) ve katalaz (CAT) enzim aktivitelerinde bir azalma, süperoksitdismutaz (SOD) enzim 
aktivitesinde ise bir yükselme olduğu belirlenmiştir(Tablo 7).

Tablo 7. Farklı yaş gruplarındaki göknar ve sarıçam ibrelerinin askorbat peroksidaz (APx), guaicol peroksidaz (GPx), katalaz (CAT) ve süperoksitdismutaz (SOD) enzim aktiviteleri $(\mathrm{p}<0.05 ; \mathrm{a}, \mathrm{b}, \mathrm{c}, \mathrm{d}, \mathrm{e}, \mathrm{f}<0.000)$

\begin{tabular}{|c|c|c|c|c|c|}
\hline \multirow[b]{2}{*}{ Ağaç türü } & \multicolumn{2}{|l|}{ Ya } & \multirow[b]{2}{*}{$\begin{array}{l}\text { GPx (ünite/mg } \\
\text { Protein) }\end{array}$} & \multirow[b]{2}{*}{$\begin{array}{l}\text { CAT (ünite/mg } \\
\text { Protein) }\end{array}$} & \multirow[b]{2}{*}{$\begin{array}{l}\text { SOD (ünite/mg } \\
\text { Protein) }\end{array}$} \\
\hline & $\begin{array}{l}\text { ș } \\
\text { (yll } \\
\text { ) }\end{array}$ & $\begin{array}{l}\text { APx (ünite/mg } \\
\text { Protein) }\end{array}$ & & & \\
\hline \multirow{4}{*}{ Göknarı } & 38 & 0 & $01 * \mathrm{~d}$ & sc & $\mathrm{b}$ \\
\hline & 60 & & $002 * c$ & 0.088 & 118. \\
\hline & 90 & $0.40 \pm 0.0012^{* \mathrm{~d}}$ & $0.0060 \pm$ & 0.104 & $123.8 \pm 0.002 * c$ \\
\hline & 100 & & $0.0050 \pm 0$ & $0.033 \pm 0.0$ & $238.1 \pm 0.003 * \mathrm{f}$ \\
\hline \multirow{2}{*}{ Sarıçam } & 18 & & & $0.033 \pm 0$. & $226.3 \pm 0.000 * d$ \\
\hline & 30 & $0.59 \pm 0.0010^{* \mathrm{e}}$ & $0.0006 \pm 0.00002 * a$ & $0.029 \pm 0.0002^{* \mathrm{a}}$ & $236.7 \pm 0.0012^{* \mathrm{e}}$ \\
\hline
\end{tabular}

\section{Tartışma}

Uludağ göknarı ve sarıçam ibrelerinin içerdiği fotosentetik pigmentler, prolin, toplam çözünür protein, lipit peroksidasyonu seviyesi, hidrojen peroksit konsantrasyonu, çözünür şekerler (glikoz, fruktoz ve sakkaroz) ve toplam nişasta miktarları ve antioksidan enzim aktiviteleri, ağaç yaş grupları ve yetiştiği ortamın toprak özellikleriyle önemli derecede değişiklik göstermiştir.

Prolin ve protein miktarı Uludağ göknarı ve sarıçamın genç ibrelerinde; $\mathrm{H}_{2} \mathrm{O}_{2}$, glikoz, fruktoz, sakkaroz ve nişasta değerlerinin ise yaşlı ibrelerinde daha yüksek olarak belirlenmiştir. Enzim aktiviteleri ise 90 yaşındaki göknar ile genç sarıçam ibrelerinde daha fazla bulunmuştur. Tespit edilen bu farklılıklar, bitki büyüme ve gelişim fizyolojisinin, ağaç yaşı ve çevresel faktörlere göre değişebileceği sonucunu doğrulamaktadır. Birçok araştırıcı, senesense uğramış doku ve organlarda fotosentezin baskılanması sonucu ATP üretiminin; protein sentezinin baskılanması ve protein yıkımının artmas1 sonucu çözünür protein değerinin düştüğünü buna karşın amino asit, glikoz, fruktoz ve sakkarozun ve $\mathrm{H}_{2} \mathrm{O}_{2}$ miktarının ise yükseldiğini bildirmiştir (Kanazawa ve ark., 2000; Reyes-Arribas ve ark., 2001; Palma ve ark., 2002; Tsanko ve ark., 2005). Optimal koşulların kötüye gitmesi ve yaşlanmanın uyarıldığ 1 dönemlerde gerekli enerji, solunum yoluyla temin edildiğinden, yaşlı yaprak ve dokularda solunum hizlanmakta, sakkarozun basit şekerlere parçalanması ile hücrelerde glikoz ve fruktoz miktarı artış göstermektedir (Dickinson ve ark., 1991; Krömer, 1995; Plaxton, 1996; Reyes-Arribas ve ark., 2001).

Ağaç türü, yaş1 ve toprak özelliklerinin kimyasal bileşenlere etkileri, fotosentetik pigmentleri prolin ve protein miktarlarında oldukça belirgindir. En düşük klorofil a, klorofil b, toplam klorofil ve karotenoit değerleri 100 yaşındaki Uludağ göknarı ibrelerinde saptanırken, 90 ve 38 yaşındaki Uludağ göknarı ibreleri en yüksek değerleri göstermiştir. Sarıçam ibrelerin de ise; 18 yaşındaki sarıçam ibreleri klorofil a, klorofil $\mathrm{b}$, toplam klorofil ve karotenoit değerleri bakımından en yüksek değerlere sahip olmuştur (Tablo 4). 90 yaşındaki göknar ağacında pigment değerlerinin yüksek olmas1, literatür verilerine ters düşmektedir. Ancak bu ağaçta APx, CAT ve SOD aktivitelerinin yüksek, ağacın lokasyonunda toprak hacim ağırlığı, organik madde, $\mathrm{K}$ miktarının uygun olması pigment değerinin korunmasında etkili olmuş olabilir. Ayrıca prolin ve protein MDA ve $\mathrm{H}_{2} \mathrm{O}_{2}{ }^{\prime}$ nin toksik etkisinin giderilmesinde kullanıldığ 1 için azalmış ve fotosentetik aktivitenin yüksek olmasına sebep olmuş olabilir. En genç göknar ve sarıçam ağaçlarının ibrelerinde pigment miktarlarının iyi olmasında ise yaş faktörü öne çıkmaktadır. Bununla birlikte yaş, APx, K, organik madde genç göknar ağacinda; yaş, prolin, protein, APx, CAT, organik madde, $\mathrm{K}$ ve $\mathrm{pH}$ ise en genç sarıçam ağacında pigment miktarlarının yüksek olmasında etkili olmuş olabilir. 
Prolin, çözünür proteinler, çözünür şekerler yapıya katılarak sentez olaylarında ve enerji üretiminde, lipit peroksidasyonu, reaktif oksijen türlerinin artması, hücre içi hemeostasisinin bozulmas1 durumunda zar bütünlügünün sağlanması, DNA, RNA ve enzimlerin yapısının korunması ve ozmotik potansiyelin düzenlenmesinde kullanıldıkları için, hücre içerisindeki miktarları zaman zaman değişmektedir (Jain ve ark., 2001; Palma ve ark., 2002; Hammond ve White, 2008; Heidari ve Moaveni, 2009; Keyvan, 2010). 38 yaşındaki göknar ve 18 yaşındaki sarıçam ağaçlarının ibrelerinin prolin ve protein miktarının yüksek, MDA içeriğginin düşük olması ve ayrıca organik madde ve $\mathrm{K}$ içeriğinin uygunluğu, kloroplast zarlarının ve zarda lokalize olan pigmentlerin korunduğunu işaret etmektedir (Çakmak, 1994; Manuela ve ark., 1998; Zheng ve ark., 2004; Ponge ve Chevalier, 2006; Foyer ve Shigeoka, 2011; Cruz ve ark., 2013).

Büyüme ve gelişimin normal seyrinde, hücrelerdeki lipit peroksidasyonu oldukça düşüktür. Ancak çevresel koşullardan sapma ve yaşlanma gibi fizyolojik değişimler, oskidatif strese neden olarak zarlardaki lipit yapıs1 ve kompozisyonu etkilerler. Zar bütünlüğünün bozulması ve MDA birikimi olarak beliren lipit peroksidasyonu reaktif oksijen (ROS) türlerinin üremesine, proteinler, DNA ve RNA'nın denaturasyonuna neden olarak, büyüme ve gelişmeyi baskılarlar. Bitkiler oskidatif stresin zararlı etkisini yok etmek için APx, CAT, GPx ve SOD gibi enzimlerini aktifleştirirler (Jain ve ark., 2001; Quan ve ark., 2008; Soydam ve Aras, 2012).

Göknar ve sarıçam ibrelerinde, MDA miktarı ve toprak özellikleri arasında önemli bir ilişki bulunamamıştır. Ancak MDA içeriğinin düşük olduğu ibrelerde, prolin miktarının yüksek olması, buna karşın MDA'nın yüksek olduğu durumlarda SOD, APx, GPx ve CAT ektivitelerinin yüksek olması, MDA hasarının giderilmesinde bu bileşiklerin daha etkin olduğunu göstermektedir.

Glikoz ve fruktoz nişasta sentezi ve solunumun reaksiyonlarının anahtar bileşikleridir. Fruktoz ayrıca glikoliz ve sakkaroz sentezi arasındaki paylaşımın belirlenmesinde rol oynamaktadır.
Fotosentezde fikse edilen her bir karbonun kloroplastlarda nişastaya m1 yoksa sitoplazmada sakkaroza $\mathrm{m}$ dönüştürüleceği, fruktoz miktarı ile kontrol edilmektedir. Eğer sitoplazmada fruktoz miktarı yüksek ise sakkaroz içeriği düşüktür. Sakkaroz floemde en fazla taşınan şekerdir (Stitt ve Cseke, 1987; Huber, 1986; Winter, 2000; Lohaus ve Fischer, 2002; Rolland ve ark., 2002; Hammond ve White, 2008).

Her iki ağaç türünde glikoz, fruktoz, sakkaroz ve nişasta miktarı genç ağaçlarda düşük, 100 ve 90 y1llık ağaçlarda yüksektir. Ayrıca yaşlı göknar ağaçlarında yaş, ağaç çapı, şekerler ve nişasta miktarları ile $\mathrm{pH}$ ve toprak hacmi arasında pozitif bir ilişki gözlenirken, ölü örtü miktarı ve toprak hacim ağırlığı, $\mathrm{K}$ içeriği ile yaş arasında ise negatif ilişki sözkonudur. Sarıçam ağaçlarında yaş, çap, şekerler, organik madde, ölü örtü miktarı ve toprak hacim ağırlığı ve ayrıca $\mathrm{K}$ içeriği yaşla birlikte artış gösterirken, toprak hacim ağırlığı yaşın aksine azalmıştır. Bu sonuç, karbohidrat metabolizmasının yaşa bağlı olarak yavaşladığını; genç bitkilerde şekerlerin aktif büyüme gösteren doku ve organlarında polisakkaritlerin ve diğer makromoleküllerin sentezinde kullanılması nedeniyle azaldığını ve ayrıca da karbohidrat metabolizmasının toprak özelliklerinden etkilendiğini göstermektedir (Lohman ve ark., 1994; Krömer, 1995; Krugger, 1997; Eubel ve ark., 2003; Llyod ve ark., 2005; Kruger ve Volin, 2006). Nitekim yaşlanmış doku ve organlarda solunum hizının artmasına paralel olarak hücrelerde glikoz ve fruktoz miktarının arttığ 1 yukarıdaki literatürlerde de belirtilmiştir. Ağaçlarda çap gelişiminin karbohidrat metabolizması ve çevresel faktörlerden etkilenmekle birlikte daha çok bitki ömrü ile ilişkili olduğu görülmektedir. Ağaç çapının her iki ağaç türünde de genç ağaçlarda düşük, yaşlı ağaçlarda yüksek olması, 60 yaşındaki ağaçta kötü kimyasal verileri ve toprak özelliklerine karşın ağaç yaşına bağlı kronolojik sırayı bozmaması bu sonucu güçlendirmektedir.

Bitkilerde hidrojen peroksit $\left(\mathrm{H}_{2} \mathrm{O}_{2}\right)$ konsantrasyonunun artması, çevresel değişimlere karşı genel bir tepki olduğu ileri sürülmektedir. Bu bileşik, biyotik ve abiyotik stres etmenlerine karşı tepki genlerinin uyarılmasında ve metabolizmalarının 
değiştirilmesinde sinyal molekül olarak iş görmektedir (Smirnoff ve Cumbes, 1989; Foyer ve Noctor, 2005; Tanou ve ark., 2012; Cruz ve ark., 2013). Hem göknar hem de sarıçam ağaçlarında, yaşlı ağaçlarda $\mathrm{H}_{2} \mathrm{O}_{2}$ miktarının yüksek olması, bu ağaçların hücre, doku ve organlarında senesensin başlaması ve ayrıca vasküler dokularda görülen apoptozis olayları ile ilişkili olabileceğini düşündürmektedir.

Senesens, bitkilerde anabolik reaksiyon yönünün yaşa bağlı olarak katabolik reaksiyona dönmesi sonucu hücre, doku, organ ve organizma düzeyinde oluşan ölüm ya da yaşam döngüsünün sona ermesi olayıdır (Yoshidai 2003; Gregersen ve ark., 2013; Gully ve ark., 2015). Nitekim birçok araştırıcı sensense uğramış yapraklarda $\mathrm{H}_{2} \mathrm{O}_{2}$ miktarının arttığını söylemişlerdir (Lohman ve ark., 1994; Gechevt ve ark., 2002; Tsanko ve ark., 2005; Gregersen ve ark., 2013). Bitkilerde senesen, apoptozis veya nekroz ile belirli dokuların oluşması/belirli dokuların elimine edilmesi, zarar gören veya patojen istilasına uğramış hücrelerin öldürülmesi ve istenmeyen her türlü hücre, doku ve organların elimine edilmesi sağlanmaktadır (Pennel ve Lamb, 1997; Gan, 2003; Kacprzyk ve ark, 2011). Örneğin vasküler hücrelerde (ksilem) apoptozis ile hücre ölümleri, suyun bir sütun halinde taşınması sağlayan kanalların oluşumu sağlandığı gibi patojenlerin iletim demetleri içerisinde yayılması ve zararı engellenmiş olur. Araştırıcılar vasküler dokulardaki hücre ölümlerinin $\mathrm{H}_{2} \mathrm{O}_{2}$ peroksit ile uyarıldığını (Carrington ve ark., 1996). Ayrica odunsu bitkilerde enine büyüme vasküler kambiyal hücrelerin yılda iki kez bölünmesi ile oluşmaktadır. Her bölünme evresinde kambiyal meristemden öze doğru yeni ksilem, kambiyal halkadan gövdenin kabuğuna doğru da yeni floemler oluşmakta ve oluşan halkalar ile de bitki yaşı ve ağaç çapı belirlenmektedir (Lanner ve Connor, 2001; Lanner, 2002 Frankenstein ve ark., 2005). Yaşlı ağaçlarda kambiyal aktiviteye bağlı olarak iletim demetlerinin daha yoğun bulunması, toprak hacim ağırlığı ve ağaç hacmine bağlı olarak su gereksiniminin daha fazla olması, yaşlı göknar ve sarıçamlarda $\mathrm{H}_{2} \mathrm{O}_{2}$ 'nin neden daha fazla olduğunu açıklamaktadır.
60 yaşındaki göknarda kimyasal bileşiklerin kötü değer sergilemesi, bu ağaçta büyüme ve gelişmenin dengeye doğru kaymış olması ile açıklanabilir. Daha önce de ifade edildiği gibi sentez ve yıkım olayları büyüme ve gelişmenin olgunlaşma safhasında denge halinde bulunmaktadır. $\mathrm{Bu}$ ağaçta pigment ve şekerlerin düşük olması bu sonucu doğrulamaktadır. 60 yıllık göknarda MDA miktarının en yüksek, $\mathrm{H}_{2} \mathrm{O}_{2}$ içeriğinin ise en düşük değerinde olması ve ayrıca protein miktarının da yaşlı göknarlara göre daha yüksek olması, ağaç yaşının olgunluk evresini henüz tamamlamadığına işaret etmektedir. Bununla birlikte bu ağacın toprak yapısında kum içeriğinin, ölü örtü ve toprak hacim ağırlığının en düşük değerde olması, kök gelişiminin baskılanması yoluyla topraktan gerekli minerallerin alınmasını ve fotosentez ve karbohidrat metabolizmasinı yavaşlattı̆ğını (Marschner, 1995; Manuela ve ark., 1998; Viet ve ark., 2003), fotosentetik pigment miktarlarının düşük, MDA içeriğinin yüksek olmasına neden olduğunu işaret etmektedir.

En yaşlı göknar ağacında klorofil pigmentleri hem diğer göknar ağaçları hem de sarıçam ağaçlarına göre en düşük değerindedir. Yine en düşük MDA, APx ve CAT aktivitesi, ölü örtü, organik madde, toprak hacim ağırlığı ve $\mathrm{K}$ içeriği bu ağaçta saptanmıştır. Buna karşın fruktoz, sakkaroz, ağaç çap1 ve SOD aktivitesi ise en yaşlı göknar ağacında yüksektir. Fruktoz ve glikozun yüksek olması solunumun ve sakkarozun parçalanma hızının arttı̆̆ını göstermektedir. $\mathrm{H}_{2} \mathrm{O}_{2}$, glikoz ve nişasta, 90 y1llık ağaçtan sonra en fazla bu ağaçta bulunmaktadır. Yaşlı ağaçlarda ağaç çapı, $\mathrm{H}_{2} \mathrm{O}_{2}$ ve şekerlerin yüksek, pigment ve protein miktarının düşük olması beklenen bir durumdur.

Göknar ağaçlarında toplam ölü örtü, organik madde ve kil miktarı, L, H ve $\mathrm{K}+$ (potasyum) arasında pozitif ilişki gözlenirken, toplam ölü örtü, organik madde ve kil miktarı, L (ölü örtü tabakası), H (humus tabakasi) ve $\mathrm{K}$ arasinda $\mathrm{pH}$ ile negatif ilişki sözkonusudur. Potasyum en fazla kil minerallerinde bulunmaktadır. Toprakta minerallerde bağlı olan potasyumun $(\mathrm{K}+)$ miktarı anakayanın minerolojik bileşimine göre değişirken, toprağın 
değiştirilebilir potasyum miktarı $(\mathrm{K}+)$ ise anakayanın mineralojik bileşiminden çok toprağın kolloid madde miktarına ve toprak horizonlarına göre değişir. Toprakta potasyumun değiştirilebilir durumda tutulması kil miktarına önemle bağlıdır (Rowell, 1989; Marschner, 1995; Tan, 2003).

Bizim çalışmamızda göknar ağaçlarına ait toprakta kil miktarı yaş arttıkça azalmış olması, K miktarının da azalmasında etkili olabileceğini akla getirmektedir. Bununla birlikte topraktaki $\mathrm{K}+$ oranı $\mathrm{pH}$ ve yağışla da yakından ilişkilidir. Asit reaksiyonlu topraklarda potasyum kolayca yıkanırken, nötr ve alkali reaksiyonlu topraklarda potasyum miktarı daha fazladır. Yağışlar topraktaki değiştirilebilir $\mathrm{K}+$ 'u yıkayıp götürebilmektedir. Nitekim Kantarc1 (1979) Uludağ göknarında yükselti attıkça artan yağışın toprakta $\mathrm{K}+$ iyonunun yıkanmasına neden olduğunu, $900-1000 \mathrm{~m}$ kuşağında yağışın daha az, sıcaklığın daha yüksek olması nedeniyle ölü örtüde $\mathrm{K}+$ miktarının daha fazla olduğunu bildirmiştir.

Göknar ağaçlarında ölü örtü miktarı genç ağaçlardan yaşlı ağaçlara doğru artış gösterirken, sarıçam ağaçlarında yaș arttıkça artma eğilimi göstermesi; bitki türüne bağl1 olarak yaş faktörünün kök ve toprak solunumu ve ayrıca toprarağın mikrobiyal aktivitesi üzerinde etkisi olduğunu düşündürmektedir.

\section{Sonuç}

Çalışmada 90 yaşındaki Uludağ göknarı ve 18 yaşındaki sarıçam meșçerelerinin daha üstün özelliklere sahip olduğu belirlenirken, 38 yıllık göknar ve 30 yaşındaki sarıçam ağaçlarının ara grup oluşturduğu saptanmıștır. Anabolik faaliyetler her iki ağaç türünde genç ağaçlarda; katabolik faaliyetler, senesens belirtileri ve şeker birikimi ise yaşlı ağaçlarda yüksek bulunmuştur. İncelenen kimyasal bileşenler, toprak $\mathrm{pH}$, ölü örtü, organik madde, $\mathrm{K}+$ içeriğinden etkilenirken, karbon (C) miktarı ve kimyasal bileşimler arasında bir ilişki bulunamamıştır. Ancak gerek Uludağ göknarı meşçerelerinde gerekse sarıçam meşçerelerinde en düşük $\mathrm{C}$ içeriğinin, en yüksek $\mathrm{pH}$, düşük ölü örtüde saptanması, $\mathrm{C}$ miktarının, ölü örtü, $\mathrm{pH}$ ve toprağın mikroorganizması ile ilișkili olduğuna ișaret etmektedir. Ayrıca göknar ağaçlarında ölü örtü, organik madde miktarı azalımı ile $\mathrm{K}+$ miktarının değişimi ve ayrıca sarıçamlarda yaşlanmaya paralel olarak ölü örtü, organik madde ve K+ içeriğinin artması, ayrışma ve $\mathrm{K}+$ arasında önemli bir ilişki bulunmaktadır. Ölü örtü miktar değişimlerine bağlı olarak sarıçam ağaçlarına ait lokasyondaki ölü örtü materyallerinde daha fazla lignin bulunduğu, buna karșın göknar ağaçlarına ait materyallerde daha düşük lignin bulunduğu ve bu nedenle göknar ağaçlarına ait ölü örtünün daha kolay ayrışmış olabileceği de söylenebilir. Ağaç çapı, her iki ağaç türünde metabolik aktivite ve toprak özelliklerinden ziyade ağacın yaşından etkilenmiştir.

Bulgular doğrultusunda bitki büyüme ve gelişmesinin bitki türü, bitkinin gelişim sürecindeki gelişmişlik seviyesi, yaşı, genetik yap1 ve toprak özelliklerine bağlı olarak değiştiği, topraktaki $\mathrm{C}$ miktarının toprak pH'ı, ölü örtü miktarı ve parçalanma hızı ile ilişkili olduğu ve ayrıca her iki bitki grubu ele alındığında ise göknarın daha tolerant olduğu söylenebilir.

\section{Kaynaklar}

Akbaş B., Akdeniz N., Aksay A., Altun İ., Balcı V., Bilginer E., Bilgiç T., Duru M., Ercan T., Gedik İ., Günay Y., Güven İ.H., Hakyemez H.Y., Konak N., Papak İ., Pehlivan Ş., Sevin M., Şenel M., Tarhan N., Turhan N., Türkecan A., Ulu Ü., Uğuz M.F., Yurtsever A. vd. 2014. Türkiye Jeoloji Haritası Maden Tetkik ve Arama Genel Müdürlüğü Yayını. Ankara, Türkiye.

Arnon D.I. 1949. Copper enzymes in isolated chloroplast. Polyphenoloxidase in Beta vulgaris. Plant Physiology 24: 1-10.

Atkin O.K,, Scheurwater .I, Pons TL. 2007. Respiration as a percentage of daily photosynthesis in whole plants is homeostatic at moderate, but not high, growth temperatures. New Phytologist 174: 367-380.

Bates L.S., Waldern R.P., Teare I.D. 1973. Rapid determination of free proline for waterstress studies. Plant and Soil 39: 205-207.

Bauer H., Bauer U.1980. Photosynthesis in leaves of the juvenile and adult phase of ivy (Hedera helix). Physiol Plant 49:366-372.

Berges L., Chevalier R., Dumas Y., Franc A., Gilbert J.M. 2005. Sessile oak (Quercus petraea Liebl.) site index variations in relation to climate, topography and soil in even-aged high-forest stands in northern France. Ann. For. Sci. 62 (5), 391-402. 
Bergmeyer, H.U. 1974. Methods of Enzymatic Analysis. New York, Academic Press.

Blake G.R. 1965. Bulk density. In: The effects of different land uses on soil microbial biomass carbon and nitrogen in Bartın province. (Kara, O \& Bolat, I), Turk J. Agric. F. 32 (2008) 281-288.

Bond B.J. 2000. Age-related changes in photosynthesis of woody plants. Trends Plant Science 5: 349-353.

Bouyoucos G.J. 1936. Direction for Making Mechanical Analysis of Soils by the Hydrometer Method, Soil Science, 42, 225-229.

Bouyoucos G.J. 1962. Hydrometer method improved for making particle size analyses of soils. Agron. J. 54: 595-622.

Bradford M.M. 1976. A rapid and sensitive method for the quantitation of microgram quantities of protein utilizing the principle of protein-dye binding. Analyt. Biochem.,72(1-2), 248-254.

Cakmak I. 1994. Activity of ascorbatedependent $\mathrm{H} 2 \mathrm{O} 2$-scavenging enzymes and leaf chlorosis are enhanced in magnesium and potassium deficient leaves, but not in phosphorus deficient leaves. J. Exp. Bot. 45, 1259-1266.

Cakmak I., Engels C. 1999. Role of mineral nutrients in photosynthesis and yield formation, in Rengel, Z.: Mineral Nutrition of Crops: Mechanisms and Implications. The Haworth Press, New York, USA, pp. 141-168.

Cakmak I., Graham R., Welch RM. 2002. Agricultural and molecular genetic approaches to improving nutrition and preventing Micronutrient malnutrition globally. In Encyclopedia of Life Support Systems (section eds I. Cakmak \& R.M. Welch), UNESCO-EOLSS Publishers Co. Ltd.,UK, pp: 1075-1099.

Carrington J.C., Kasschau K.D., Mahajan S.K., Schaad M.C. 1996. Cell-to-cell and long distance transport of viruses in plants. Plant Cell 8: $1669-1688$.

Carus S. 1995. Aynı Yaşlı Doğu Kayını (Fagus orientalis Lispky.) Meşcerelerinde Çap Artımının Meşcere Yağış ve Göğüs Yüzeyine Göre Değişimi. İ.Ü. Orman Fak. Der., Seri B, Cilt 45, Sayı 3-4, 95-109 s.

Chong C.W., Tan G.A., Wong R.C., Riddle, M.J., Tan I.K. 2009. DGGE fingerprinting of bacteria in soils from eight ecologically different sites around Casey Station, Antarctica. Polar Biology, 32(6), 853-860.

Choudhury S., Panda S.K. 2004. Induction of oxidative stress and ultrastructural changes in moss Taxithelium nepalense (Schwaegr.) broth under lead and arsenic phytotoxicity Curr Sci. 87: 342-348.

Choy E.J., Richard P., Kim K.R., Kang C.K. 2009. Quantifying the trophic base for benthic secondary production in the Nakdong River estuary of Korea using stable $\mathrm{C}$ and $\mathrm{N}$ isotopes. Journal of Experimental Marine Biology and Ecology, 382(1), 18-26.

Cruz F.J.R., Castro G.L.S., Silva Júnior D.D., Festucci-Buselli R.A., Pinheiro H.A. 2013. Exogenous glycine betaine modulates ascorbate peroxidase and catalase activities and prevent lipid peroxidation in mild water-stressed Carapa guianensis plants. Photosynthetica, 51, 102-108.

Dickinson C.D., Altabella T., Chrispeels M.J. 1991. Slow-Growth Phenotype of Transgenic Tomato Expressing Apoplastic Invertase. Plant Physiol., 95, 420-425.

DMİ 2016. Devlet Meteoroloji İşleri Gn. Md., Kastamonu Meteoroloji İl Müdürlüğü, İnebolu Meteoroloji İstasyonu Verileri, 1960-2015. Kastamonu.

Eksperiandova L.P., Fedorov O.I., Stepanenko N.A. 2011. Estimation of metrological characteristics of the element analyzer EuroVector EA-3000 and its potential in the single-reactor CHNS mode. Microchemical journal, 99 (2), 235-238.

Eubel H., Jaencsh L., Braun H.P. 2003. A New insights into respiratory Chain of Plany mitochondria. Supercomplexes and a unique composition of complex II. Plant Physiology,133: 274-286.

Foyer C.H., Bloom A.J., Queval G., Noctor G. 2009. Photorespiratory Metabolism: Genes, Mutants, Energetics, and Redox Signaling. Annual Review of Plant Biology, Vol.60, (June 2009), pp. 455-484.

Foyer C.H., Noctor G. 2005. Oxidant and antioxidant signaling in plants: a re-evaluation of the concept of oxidative stress in a physiological context. Plant Cell Environ 28: 1056-1071.

Foyer C.H., Shigeoka S. 2011. Understanding oxidative stress and antioxidant functions to enhance photosynthesis. Plant Physiol. 155: 93100.

Frankenstein C., Eckstein D., Schmitt U. 2005. The onset of cambium activity- a matter of agreement? Dendrochronologia 23: 57-62.

Gan S. 2003. Mitotic and Postmitotic Senescence in Plants. Sci. Aging Knowl. Environ., 2003 (38), RE7.

Gechevt T., Gadjev I., Breusegem F.V., Inzed D., Dukindjiev S Toneva V., Minkov I. 2002. Hydrogen peroxide protects tobacco from oxidative stress by inducing a set of antioxidant enzymes. Cell. Mol. Life Sciences 59-708.

Gitelson A.A., Zur Y., Chivkunova O.B., Merzlyak M.N. 2002. Assessing carotenoid content in plant leaves with reflectance spectroscopy. 
Göl C., and Öner R. 2003. Çankırı-EldivanKorubaşı Mevkii Doğal ve Yapay Orman Kuruluşlarının Bazı Toprak ve Silvikültürel Özellikleri Yönünden İncelenmesi. Gazi Üniversitesi, Orman Fakültesi Dergisi: 3-1, 1-18.

Gregersen P.L., Culetic A., Boschian L., Krupinska K. 2013. Plant senescence and crop productivity. Plant Mol. Biol., 82, 603-622.

Gully K., Hander T., Boller T., Bartels S. 2015. Perception of Arabidopsis AtPep peptides, but not bacterial elicitors, accelerates starvation induced senescence. Front. Plant. Sci., doi:10.3389/fpls.2015.00014.

Gülçur F. 1974. Toprağın Fiziksel ve Kimyasal Analiz Metodları, İstanbul Üniversitesi Orman Fakültesi Yayınları, İ. Ü. Yayın No: 1970, O. F. Yayın No: 201, Kutulmuş Matbaası, İstanbul.

Hammond J.P., White P.J. 2008. Sucrose transport in the phloem.. Integrating root responses to phosphorus starvation. Journal Experimintal Botany 59: 109-113.

Heidari Y., Moaveni P. 2009. Study of drought stress on ABA accumulation and proline among in different genotypes forage corn. Res. J. of Biol Sci, 4(10): 1121-1124.

Huber S.C. 1986. Fructose 2,6 biphosphate as a regulatory metabolits in plants. Annu. Rev. Plant. Physiol. Platn Mol Biol. 37: 233-246.

Huber S.C., Huber J.L. 1996. Role and regulation of sucrose-phosphate synthase in higher plants. Annu. Rev. Plant. Physiol. Platn Mol Biol. 47: 431-444.

Huber S.C.1984. Biochemical basis for effects of $\mathrm{K}$ deficiency on assimilate export rate and accumulation of soluble sugars in soybean leaves. Plant Physiol. 76: 424-430.

Irmak A. 1954. Arazide ve laboratuvarda toprağın araştırılması metodları. İst. Ünv. Yay. No:559. Orman Fakültesi Yay No:27, Halk Matbaas1, İstanbul.

Jackson M.L. 1962. Soil Chemical Analysis, Constable and Company Ld., London, England.

Jain M., Mathur G., Koul S., Sarin NB. 2001. Ameliorative effects of proline on salt stressinduced lipid peroxidation in cell lines of ground nut (Arachis hypogea L.). Plant Cell Rep. 20: 463-468.

Kacprzyk J., Daly C.T., McCabe P.F. 2011. The Botanical Dance of Death: Programmed Cell Death in Plants. Advances in Botanical Research. K. Jean-Claude and D. Michel, Academic Press. Volume 60: 69-261.

Kadıoğlu A. 2004. Bitki fizyolojisi. Trabzon: Lokman Yayın, 453.

Kanazawa S., Sano S., Koshiba T., Ushimaru T. 2000. Changes in Antioxidative Enzymez in Cucumber Cotyledons during Natural
Senescence: Comparison with Those during Dark-Induced Senescence. Physiol. Plant., 109, 211-216.

Kantarc1 M.D.1979. Aladağ Kütlesinin (Bolu) Aklanındaki Uludağ Göknarı Ormanlarındaki Yükselti-iklim Kuşaklarına Göre Bazı Ölü Örtü ve Toprak Özelliklerinin Analitik Olarak Araştırılması, İstanbul Üniversitesi Yayınları, No: 2634, Orman Fakültesi Yay. No:274, Matbaa Teknisyenleri Basımevi, İstanbul.

Keyvan S. 2010. The effects of drought stress on yield, relative water content, proline, soluble carbohydrates and chlorophyll of bread wheat cultivars. Journal of Animal \& Plant Sciences. Vol. 8, Issue 3: 1051- 1060.

Krömer S. 1995. Respiration during photosynthesis. Annual Reviews of Plant Physiology and Plant Molecular Biology, 46:4570 .

Kruger E.L., Volin J.C. 2006. Re-examining the Empirical Relationship Between Plant Growth and Leaf Photosynthesis. Functional Plant Biology, Vol.33, No.5, (May 2005),pp. 421-429.

Krugger R. 1997. Carbohydrate synthesis and degradation. In Plant Metabolism, 2nd ed, DT Dennis, Turpin D.H., Lefebvre D.D., Layzell D.B., Longman, Singapore, pp:83-104.

Lanner R.M. 2002. Why do trees live so long? Ageing Research Reviews 1: 653-671.

Lanner R.M., Connor K.F. 2001. Does bristlecone pine senesce? Experimental Gerontology 36: 675-685.

Levitt J. 1980. Responses of Plants to Environmental Stresses, Vol. II. 2nd ed. Academic Press. NewYork, 607 pp.

Lichtenhaler H.K. 1996. Vegetation stress: An introduction to the stress concept in plants. J Plant Physiol, 148: 4-14.

Llyod J.R., Kossmann J., Ritte G. 2005. Leaf starch degradation comes out of the shadow. Trends in Plant Science, 10: 130-137.

Lohaus G., Fischer K. 2002. İntracellular and intercellular transport of nitrogen and carbon. In Foyer C.H. and Noctor G., (eds), Advances in Photosytnhesis: Photosynthetic Assimilation and Associated Carbon Metabolism,pp:239-263. Kluwer Academic Publishers, Dordrecht, Niederlande.

Lohman K.N., Gan S., John CM., Amasino R. 1994. Molecular Analysis of Natural Leaf Senescence in Arabidopsis thaliana. Physiol. Plant., 92, 322-328.

Lutts S., Kinet J.M., Bouharmont J. 1996. Effects of various salts and of mannitol on ion and proline accumulation in relation to osmotic adjustment in rice (Oryza sativa L.) callus cultures. J. Plant Physiol. 149, 186-195. 
Makineci E. 1999. Araştırma Ormanındaki Baltalıkların Koruya Dönüştürülmesi İşlemlerinin Ölü Örtü ve Topraktaki Azot Değişimine Etkileri. Doktora Tezi, İstanbul Üniversitesi, 213s. İstanbul.

Manuela D.M., Coelhe D., Barrote I., Maria J.C.1998. Leaf age effects on photosynthetic activity and sugar accumulation in droughted and rewatered Lupinus albus plants. Australian Journal of Plant Physiology. 25(3) 299-306.

Marschner H. 1995. Mineral Nutrition of Higher Plants. 2nd ed.,Academic Press, San Diego, USA.

Marschner H., Cakmak I. 1989. High light intensity enhances chlorosis and necrosis in leaves of zinc-, potassium- and magnesiumdeficient bean (Phaseolus vulgaris) plants. J. Plant Physiol. 134: 308-315.

Moura J.C.M.S., Bonine C.A.V., de Oliveira F.V.J., Dornelas M.C., Mazzafera P. 2010. Abiotic and biotic stresses and changes in the lignin content and composition in plants. $J$. Integr. Plant Biol.52, 360-376.

Moura-Sobczak J., Souza U., Mazzafera P. 2011. Drought stress and changes in the lignin content and composition in Eucalyptus. BMC Proc. 5, 103.

Nakano Y., Asada K. 1981. Hydrogen peroxide is scavenged by ascorbate-spesific peroxidase in spinach chloroplasts. Plant Cell Physiol. 22 (5): 867-880.

Özyuvacı N. 1976. Arnavutköy Deresi Yağış Havzasında Hidrolojik Durumu Etkileyen Bazı Bitki-Toprak-Su İlişkileri. İ.Ü. Orman Fak. Yay. No:221, İstanbul.

Pearson D., Melon H.K., Ronald S. 1976. Chemical analysis of Food,8th edition.

Pennell R., Lamb C.1997. Programmed Cell Death in Plants.The Plant Cell 9: 1157-1168.

Plaxton W.C. 1996. The organisation and regulation of plant glycolysis. Annu. Rev. Plant Physiol. Plant Mol. Biol. Pp:47: 185-214.

Ponge J.F., Chevalier R. 2006. Humus index as an indicator of forest stand and soil properties. For. Ecol. Manage. 233 (1), 165-175.

Quan L.J., Zhang B., Shi W.W., Li H.Y. 2008. Hydrogen peroxide in plants: A versatile molecule of the reactive oxygen species network. J Integrat Plant Biol, 50: 2-18.

Reyes-Arribas T., Barrett J.E., Huber D.J., Nell T.A., Clark D.G. 2001. Leaf Senescence in A Non-Yellowing Cultivar of Chrysanthemum (Dendranthema grandiflora). Physiol. Plant., 111, 540-544.

Rolland F., Moore B., Sheen J. 2002. Sugar Sensing and Signaling in Plants. Plant Cell, 14, S185-S205.
Rowell D.L. 1989. Soil acidity and alkalinity. In: Russell's soil conditions and plant growth. Ed. A. Wild. Department of soil science, University of Reading. The Bath Press., Avon.

Rowell D.L. 1994. Soil science: methods and applications. Longman Scientific and Technical, Singapore.

Sariyildiz T., Anderson J.M. 2005. Variation in the chemical composition of green leaves and leaf litters from three deciduous tree species growing on different soil types. Forest Ecology and Management, 210 (1-3), 303-319.

Sariyildiz T., Anderson J.M. 2006. Intraspecific variation in cell Wall constituents of needle age classes of Pinus sylvestris in relation to soil fertility status in Southwest England. Silva Fennica 40(1): 15-26.

Sariyildiz T., Küçük M. 2009. Influence of slope position, stand type and rhododendron (Rhododendron ponticum) on litter decomposition rates of oriental beech (Fagus orientalis Lipsky.) and spruce (Picea orientalis (L.) Link). Eur. J. Forest Res. 128: 351-360. doi:10. 1007/s10342009-0270-x.

Sevik H. 2012. Variation in seedling morphology of Turkish fir (Abies nordmanniana subsp. bornmulleriana Mattf), African Journal of Biotechnology, 11(23): 6389-6395.

Sevik H., Topacoglu, O. 2015. Variation and inheritance pattern in cone and seed characteristics of Scots pine (Pinus sylvestris L.) for evaluation of genetic diversity, Journal of Environmental Biology, 36(5):1125-1130.

Sevik H., Yahyaoglu, Z., Turna I. 2012. Determination of Genetic Variation between Populations of Abies nordmanniana subsp. bornmulleriana Mattf according to some Seed Characteristics. Genetic Diversity in Plants, ISBN 978-953-51-0185-7, Chapter 12, pp. 231-248.

Smirnoff N. 2005. Ascorbate, Tocopherol and Carotenoids: Metabolism, Pathway Engineering and Functions. In: Smirnoff N, Ed. Antioxidants and Reactive Oxygen Species in Plants. Oxford: Blackwell Publishing Ltd.p:53-86.

Smirnoff N., Cumbes Q.J. 1989. Hydroxyl radical scavenging activity of compatible solutes. Phytochemistry, 28: 1057-60.

Sevik H., Topaçoğlu O., Umur R., Çiftçioğlu S. 2013. Uludağ Göknarı (Abies nordmanniana subsp. bornmülleriana mattf.)'nda 2+1 Yaşl1 Fidan Morfolojik Özellikleri Bakımından Populasyonlar Arası Farklılıklar. Karadeniz Fen Bilimleri Dergisi/The Black Sea Journal of Sciences 3(9):91-102.

Smith W.O., A.R. Shields J.C., Dreyer J.C., Pelouin J.A., Asper V. 2011. Interannual variability in vertical export in the Ross Sea: Magnitude, composition, and environmental 
correlates, Deep Sea Res. Oceanogr. Res. Paper 58(2), 147-159.

Soydam A.S., Aras S. 2012. Relationships among lipid peroxidation, enzyme activity and gene expression profiles of superoxide dismutase (SOD) in Lycopersicum esculentum L. exposed to cold stress, (unpublished manuscript).

Stitt M., Cseke C. 1987. Alterations of fructose 2,6-bisphosphate during plant respiratory metabolism. In M Gibbs, ed, Hungarian-USA Binational Symposium on Photosynthesis, Salve Regina College, August 15-18, 1986.

Şenyurt M., Saraçoğlu Ö. 2012. Bat1 Karadeniz Bölgesi Sarıçam (Pinus sylvestris L.) Meşcereleri İçin Bonitet Tablosunun Düzenlenmesi. Kastamonu Üni., Orman Fakültesi Dergisi, 12 (1): 102-111.

Şimşek Z., Öner N. 2003. Ilgaz (Derbent ve Doruk)'da Uludağ göknarı (Abies nordmannıana subsp. bornmulleriana mattf.) meşcerelerinin silvikültürel özellikleri ile saptanan kabuk böcekleri ve mücadele yöntemleri. Süleyman Demirel Üniversitesi Orman Fakültesi Dergisi, Seri: A, Sayı: 2, 49-60.

Tan K.H. 2003. Humic matter in soil and environment, principles and controversies, Marcel Dekker, Inc. 270 Madison Avenue, New York.

Tanou G., Job C., Rajjou L., Arc E., Belghazi M., Diamantidis G. 2009.Proteomics reveals the over lapping roles of hydrogenperoxide and nitricoxide in the acclimation of citrus plants to salinity. PlantJ. 60: 795-804.

Tsanko S.G., Hille J. 2005. Hydrogen peroxide as a signal controlling plant programmed cell deathThe Journal of Cell Biology, 168 (1):17-20.

Turkyilmaz S., Ozturk, M., Guvensen A. 2011. Proline accummulation in some coastal zone plants of the aegean region of Turkey. The European Journal of Plant Science and Biotechnology (Special Issue), Research Note Global Science Books, pp. 1-3. http://www.ogm.gov.tr/Sayfalar/Ormanlarimiz/Tu rkiyeOrmanVarligi.aspx (URL1, 2016).

Velikova V., Yordanov I., Edrava A. 2000. Oxidative stress and some antioxidant systems in acid rain-treated bean plants. Protective role of exogenous polyamines. Plant Science, 151, 5966.

Viet H.D., Kwak J.H., Lee K.S., Lim S.S., Matsushima M., Chang S.X., Lee K.H., Choi W.J. 2013. Foliar chemistry and tree ring d13C of Pinus densiflora in relation to tree growth along a soil pH gradient. Plant Soil 363, 101-112.

Wang H.L., Lee P.D., Chen W.L., Huang D.J. and Su J.C. 2000.Osmotic stress-induced changes of sucrose metabolism in cultured sweet potato cells, J. Exp.Bot., 51: 1991-1999.
Winter H., Huber S.C. 2000. Regulation of Sucrose Metbolism in Higher Plants.: Localisation and Regulation of Activity of Key Enzymes. Critical Review Plants Sciences 19: 3167.

Witham F.H., Blaydes D.F., Devlin R.M. 1971. Experiments in plant physiology. pp 55-56. Van Nostrand Reinhold Company, New York.

Yadeghari L.Z., Heidari R. Carapetian J. 2008. The influence of cold acclimation on proline, malondialdeyde (MAD), total protein and pigments contents in soybean (Glycine max) seedlings. Research J. of Biolo. Sci., 3(1):74-79.

Yoshida K. 2003. Molecular regulation of leaf senescence. Current Opinion in Plant Biology 6:79-84.Zeaaman S.C., Smith S.M., Smith A.M. 2007. The diurnal metabolism of leaf starca . Biochemical Journal 401: 13-28.

Yurtseven R., Tarakcılar, A.R., \& Topçu, M. 2013. Dolgu Maddesi Olarak Kullanılan Farklı Uçucu Küllerin Sert Poliüretan Köpük Malzemelerin Mekanik Özellikleri İle Isıl Ve Yanma Davranışları Üzerine Etkileri. Gazi Üniversitesi Mühendislik-Mimarlık Fakültesi Dergisi, 28(4).

Zheng M., Meng Y., Yang C., Zhou Z., Wang Y., Chen B. 2014. Protein expression changes during cotton fiber elongation in response to drought stress and recovery. Proteomics, 14, 1776-1795. 